\title{
AN APPLICATION OF THE MODERN TECHNOLOGICAL SOLUTIONS IN AN ORDER TO ENHANCE THE PROCESS OF DISTANCE LEARNING
}

\author{
Jevgenija Dehtjare \\ Hotel Management College, Latvia \\ Jekaterina Korjuhina \\ Hotel Management College, Latvia \\ Ilona Gehtmane-Hofmane \\ University of Latvia, Latvia
}

\begin{abstract}
An approach to the development of modern process of distance learning in the higher education requires application of modern tools and technologies. It is a known fact that distance learning is mainly online and has become a synonym of a technological progress and globalization development. However, a long time experience of working with distance students and gained feedback during a communication process made it necessary to discuss a statement: modern distance and online education must become more communicative and flexible, ensuring fast connectivity, a possibility to assess students' needs and individual approach.

The theoretical framework of the article includes the analysis of an increasing role of the communication process in the distance education. A method of application of learning solutions based on the experience realms model in order to improve student's retention for distance learning is considered as a tool in an order to retain a distant student. The study consists of the introductory part, where main prerequisites for the application of modern technological solutions in order to retain a student are given, and theoretical part where postulates of Experience Economy are analyzed and present researches related to the topic are over viewed. Methodological part is presented with an observation of existing communication tools for distance learning and methods of its application in order to retain students' attention during the process of distance learning; conclusions where main findings are summarized and proposals of offered methods and technological solutions in order to retain a student for distance learning are given.
\end{abstract}

Keywords: Distance Learning, Communication tools, Technological solutions. 


\section{Introduction}

The world is experiencing a paradigm shift, and higher education is no stranger to it (Black, et al, 2019).

Modern higher education establishments, especially private educations of the Baltic States are currently experiencing hard pressure from the open education market of the other members of the European Union on the one hand and repercussion of demographic and migration crisis on the other hand. For example, Hudenko (2019) mentions a survey, made by the University of Latvia where main category of those representatives of population of Latvia that had a desire to leave the country in the year 2016 consists of young people aged 18-24 (33\% of participants of the survey). Altogether Latvia was left by 67 thousands people during the years 2013-2017. Both Latvia and Lithuania each had lost among $20 \%$ of their population during the years 2000-2017 (Hudenko, 2019). The disappearance of youngsters means consumer decrease for education market of the Baltic countries.

Distance learning tools impressively contribute to the competitiveness increase and horizon enlargement for Higher Education Institutions (HEIs) of the given region. Most of modern education establishments are equipped both with hardware and software to support the process of distance learning.

It is possible to study anytime and anywhere nowadays thanks to the dissemination of various online educational platforms, such as Moodle and others. However, the authors' long time experience of working with distance students and gained feedback during the communication process created a necessity to discuss a statement: modern distance and online education must become more communicative and flexible, ensuring fast connectivity, a possibility to asses students' needs and apply individual approach. A student presently located perhaps thousands kilometers away from his/her Alma mater should be especially encouraged for learning and should constantly be supported. That is why not only the contents of distantly offered study courses should be seriously examined, but the common approach of study subjects delivery - how easy it is to accomplish tasks, to obtain theoretical materials as well as how fast, smooth and clear the communication process is performed, with three sides being involved - a HEI, playing a moderator and a controller's role, a tutor and a student.

\section{Aim of the study}

The object of the research are 96 higher education institutions of the Baltic States, mostly focused on provision of social sciences such as 
Business Administration, Tourism etc. (Dehtjare, 2019, p.113). The subject of the research is retention of distance learning students and according application of technological solutions in order to keep students satisfied with the study process and communication.

Research problem is determined with present worsening of demographic conditions of the Baltic States and existing desire of local targeted auditorium of HEIs to leave the region. Thus, competitiveness within the HEIs of the region increases and dissemination of such a service as distance learning both for local and overseas students could become a significant competitive advantage. However, it is never enough to launch a product (or service) on a market, a communication has to be qualitative and a service provider (here: HEI) should keep its consumer (here: student) satisfied during all period of consumption (here: distance learning process). That is why a hypothesis of the research should be formulated as follows: distance learning is a product that could contribute to the increase of competitiveness and there should be applied most of modern technological solutions in order to keep the consumers (students) retained within the process of product consumption.

Merriam-Webster dictionary (2018) gives following definition of distance learning: "a method of study where teachers and students do not meet in a classroom but use the Internet, e-mail, mail, etc., to have classes" (Merriam-Webster Dictionary, 2018). Also, Cambridge Learner`s Dictionary (2018) defines the same process as "a way of studying, especially for a degree, where you study mostly at home, receiving and sending off work by post or over the internet" (Cambridge Learner's Dictionary, 2018). Learning by post being already some kind of a relic of the past, both dictionaries agree in defining distance learning process as a process where both participants are separated from each other. As it is stated above, the depressive stagnating situation among the HEIs of the Baltic States who had faced both open EU educative market competitive advantages and according threats altogether with speedily decreasing population puts these HEIs into tough surviving position. Being currently unable to ensure increase of the domestic students due to the lack of their presence in the region, the HEIs are especially interested in expanding their areas of functioning. Distance or online (most often synonymous nowadays) learning provides great possibility for this purpose. The authors suppose postulates of Experience Economy model, stated by Pine J. and Gilmore J. (as cited in Bornschlegl \& Cashman, 2018, p.62) could be applied also as a tool to retain students' attention during their participation in a process of distance learning. With regards to education process, the selling of education products (here distance learning of study courses, services offered for sale) should be enriched with selling experience. While a customer uses 
a product, an experience occurs. Tangible products and intangible services are still external to the buyer; for all that the experience is deeply personal. There are no two people with the same experience of equal product usage as their motivation is individual and not only extrinsic but intrinsic.

One way to think about experience is across two dimensions. The first dimension corresponds to customer participation. Formal, obsolete approach for distance learning means very little involvement of both students' and tutor's in the process of distance learning and communication related. Active approach of communication and according rise of experience is observed when most of communication tools are used during the distance learning process and students feel themselves highly involved and supported both by their tutor and a HEI. The kind of experience most people think of as entertainment, applied in education process, tends to be that in which customers (here: students) participate more passively then actively (for example watching live or recorded stream of in-class lecture), their connection with the event (here: lecture material to be achieved) is more likely on of absorption than of immersion.

Educational events, such as attending a virtual webinar, tends to involve more active participation, yet students are rather outside the event than are immersed into the action. Escapist experience can teach just as well as educational events, or amuse just as well as entertainment, but they involve greater students' immersion. Recorded and submitted acting in a play with an aim to simulate application of personal selling skills and then followed online discussion with a tutor and perhaps with other students in a virtual conference mode, for example, involves both active participation and immersion in the experience. However, if the student's active participation in the process of distance learning is minimized, an escapist event becomes an experience of the fourth kind-the aesthetic. Here customers or students in our case are immersed in an activity or environment, but they themselves have little or no effect on it like watching recorded video lessons. Experience, similar to goods and services should meet a need of a customer. Still, experience is born in a process that requires direct buyer's involvement, absorption of the running process or deep immersive dive into it. The model of Experience Economy formulated by Pine and Gilmore (as cited in Bornschlegl \& Cashman, 2018, p. 63) describes buyer's involvement into the process of products or service consumption as an active or passive participation within four areas (realms) of an experience. Four areas of buyer participation and involvement aspects, such as education, entertainment, esthetic and escapist are considered to be located in between horizontal axis (where absorptive involvement is on top and immersive is below) and vertical axis (with passive participation on the left and active participation on the right). 
Bornschlegl \& Cashman (2018), scientists from James Cook University, Australia, reported about the results of a research, which aim was to study if there is a correlation between students' satisfaction with a process of distance learning and their retention in study process, simple mediation model being applied. They stated:

The distance student experience and the students' satisfaction with crucial program factors were strongly indirectly related to the students' intention to persist through the students' overall satisfaction. The results indicate that designers of tertiary distance courses should consider program factors and the characteristics of the distance student experience to ensure high levels of student satisfaction and to increase the students' intention to persist (Bornschlegl \& Cashman, 2018, p. 73).

Analyzing the Four Realms model, Bornschlegl \& Cashman (2018) suppose:

The Experience Economy model could make important contributions to the understanding of distance student retention. It could clarify the relationship between program factors, satisfaction and retention taking motivational theories into consideration. The educational literature contains little research that is directly analogous to Pine and Gilmore's. $<\ldots>$ More broadly, the literature has not considered the student experience as a whole within the student retention process. These realms seem, however, important for their motivational value (Bornschlegl \& Cashman, 2018, p. 62-63).

\section{Materials and Methods}

A method of application of learning solutions based on the experience realms model was offered by the authors in order to improve students' retention for distance learning, based on Pine and Gilmore's Four Realms Experience model (as cited in Bornschlegl \& Cashman, 2018, p.63) and own practical experience with online tutoring and thanks to the introduction of modern technological solutions into the existing distance study processes of their referred HEIs altogether with theoretical review of online sources and existing scientific publications.

Main idea of the method is that during the process of distance and/ or online learning every experience realm must be fully involved to keep maximum of students' attention. The method includes application of learning solutions - for distance learning process. The authors suppose the application of a model of Four Experience (4Es) realms application for distance learning will lead both to students' retention and respectively to competency increase for related HEIs. 
Table 1. A Method of Application of Learning Solutions - Based on the Experience Realms Model in Order to Improve Students Retention for Distance Learning (offered by authors)

\begin{tabular}{|c|c|c|c|c|}
\hline \multirow[b]{2}{*}{$\begin{array}{l}\text { Realm/ } \\
\text { Involvement } \\
\text { role }\end{array}$} & \multicolumn{4}{|c|}{ Experience Realms } \\
\hline & Educational & Entertainment & Aesthetic & Escapist \\
\hline $\begin{array}{l}\text { Absorption/ } \\
\text { Active }\end{array}$ & $\begin{array}{l}\text { Remote } \\
\text { familiarization } \\
\text { with } \\
\text { educational } \\
\text { materials and } \\
\text { assignments }\end{array}$ & & & \\
\hline $\begin{array}{l}\text { Absorption/ } \\
\text { Passive }\end{array}$ & & $\begin{array}{l}\text { Watching of } \\
\text { uploaded/sent } \\
\text { educational } \\
\text { videos, } \\
\text { broadcast/ } \\
\text { recorded } \\
\text { webinars }\end{array}$ & & \\
\hline $\begin{array}{l}\text { Immersion/ } \\
\text { Passive }\end{array}$ & & & $\begin{array}{l}\text { Design of } \\
\text { a website, } \\
\text { online } \\
\text { platform, } \\
\text { study } \\
\text { materials, } \\
\text { presentations, } \\
\text { easiness of } \\
\text { usage } \\
\end{array}$ & \\
\hline $\begin{array}{l}\text { Immersion/ } \\
\text { Active }\end{array}$ & & & & $\begin{array}{l}\text { Virtual reality, } \\
\text { augmented } \\
\text { reality, } \\
\text { role plays, } \\
\text { quests, online } \\
\text { games, online } \\
\text { conferences, } \\
\text { chat bots, } \\
\text { messenger, } \\
\text { social networks }\end{array}$ \\
\hline $\begin{array}{l}\text { Communication } \\
\text { approach } \\
\text { (tutor/student/ } \\
\text { HEI) }\end{array}$ & Formal & Formal & Formal & $\begin{array}{l}\text { Formal and } \\
\text { informal }\end{array}$ \\
\hline
\end{tabular}

Remote familiarization with educational materials and subsequent writing performance of study assignments is traditionally disseminated method and a trustful way to ensure a student with information of an offered study course, its content and objectives. Such a process of obtaining information as reading is ensured with little from both sides communication 
and sometimes even lower ability to interest a remote student, however, the absorption is high as obtained competence should be proved by suggested tasks to be accomplished afterwards.

Entertainment is an important component used in order to retain student's attention and to keep satisfaction. Videos related to topicality of studies, recorded live lectures and webinars keep attention, however, a remote student still plays passive role during watching.

Communication process plays an important role in the distance learning, application of as many as possible communication solutions and tools is also crucial in retaining a student. Communication ensures active student's involvement and according immersion into the study process altogether with continuous satisfaction and feeling of a support both from a tutor and from HEI in general.

Clemons (2005) outlines: "online educators navigate technology challenges that traditional classroom teachers rarely do. However, their goal of enhancing student learning through an enriched environment is the same" (Clemons, 2005, p.7).

Solutions offered for the application in order to retain students during their process of distance learning are overlooked in Figure 1. There is a necessity to ensure multiple ways of communication for three participants of the process, a tutor, a student, a moderator (intermediate, study department representative of HEI).

The role of the moderator and his/her contribution to the communication process shouldn't be underestimated. Some education establishments and online platforms often skip moderating action or consider it less significant, however, there is still a necessity to ensure such a position. A qualified moderator of online study process is able to:

- control learning, provide explanations on operation functions, communicate with participants regarding their study debts, monitor those with frozen activity, remind and make overall statistical monitoring of student activity with according conclusions and process improvement suggestions;

- communicate with tutors, provide explanations on operation functions for them, control tutors activity, remind and make overall statistical monitoring of tutors' activity with according conclusions and process improvement suggestions;

- download study materials into education platform or help tutors to ensure this action, provide trainings for tutors how to operate within the system;

- communicate with study department to ensure systematical notification about obtained evaluations for study courses passed by students; 
- monitor existing contents of study courses downloaded to the platform, control its quality, contact tutors, remind them to make updates of contents;

- add supporting materials;

- communicate with responsible IT specialists and network administrators to ensure stable online platform function.

The approach to modern distance learning should combine both formal and informal communication. Formal communication includes online learning with a help of educative platform, use of a website, printed manuals etc. Informal communication ensures smoother and faster interaction and helps to customize the process. Messengers, social networks could be used as the tools of informal communication altogether with the standard communication devices and tools. In accordance with the Four Realms model, informal communication tools help to retain customer's (here student's) attention, having both absorptive (requires intrinsic motivation to obtain knowledge) and immersive (requires own physical action and presence, even a virtual one) importance.

The following tools of formal and informal communication for distance learning to be applied in order to retain a student can be offered:

- Online educative (e-learning) platforms, such as Moodle, Bamboohr, E-learning Platform and others (GetApp, 2018). An online learning platform is an integrated set of interactive online services that provide trainers, learners, and others involved in education with information, tools and resources to support and enhance education delivery and management (SAP Litmos, 2018). Moodle cloud allows you to access all of special applications and services from anywhere, anytime via the internet, because the information stored on the main server (the company service provider) (Basha et al., 2019, p. 40). Among the advantages of educative platforms there are: $24 / 7$ accessibility worldwide, both tutors and students activity monitoring, ease of usage, update flexibility. However, there are several disadvantages that make this study process rather formal, such as often delay in communication between tutors, students and moderators, complicated operation, formal approach of creation of study materials due to which distance students often complain to limited information amount received comparing to full time students. There is a possibility to ensure direct chat communication between tutors and students but it usually accompanies with significant delay with answers. It is necessary to emphasize that modern educative platforms have to include mobile versions due to nowadays market requirements. Still not many of them offer such a solution. Other trend is to use elements of Augmented Reality (AR) in a process of 
distance learning. Zumoko (2018) supposes, that elements of AR in education and according learning solutions help students to "visualize complex and abstract data to achieve deeper understanding and increase knowledge retention" (Zumoko, 2018, para. 2).

- Website of education establishment that can be used as a support of educative platform, containing uploaded resources, links to study materials etc. It is possible to ensure two-way communication thanks to chat bots; however, it is not a common thing for education establishments, such as colleges and universities. Still implementation of a chat bot can help to customize communication process between a student or an applicant and education establishment, to make it smoother and more pleasant. During the research 96 websitesof the universities of the Baltic States were investigated by the corresponding author (Dehtjare, 2019, p. 113), and it was a problem sometimes to find a necessary information about study programs or where to find methodical materials etc. Chat bots can simplify process of obtaining information at once;

- Email communication is a good helper in ensuring communication process, though not the best one. Initially, "the use of emails has revolutionized the way teachers communicate with their students" (Gonsalez, 2010, p. 2). The advantages of email communication for study process are its speed, accessibility, mobility and a possibility to forward attached materials. The disadvantages are possible delays and even lost in spam folders for group sending and often exclusion of study process moderator away from the communication process between a tutor and a student;

- Phone and internet voice call providers (such as Skype etc.) are long time known tools to ensure smooth and personalized distance learning process. This function is often supported by video broadcasting. While study materials available for obtaining by e-learning platforms are a useful but still formal tool, broadcasting communication is a perfect way to ensure personalized approach. A student feels more valued and supported when listens to a voice of his tutor and sees video with him, this, indeed, is much more appreciated and feedback is almost guaranteed. Moreover, the broadcast translation can be recorded and later downloaded to e-learning platform as a supported material. It can become later available for downloading as a promotion element for prospects and interested students, or even sold as a separate audio or video study course. Thanks to globalization aspect of modern technologies, video conferences, webinars can be broadcast, recorded and disseminated throughout the world. For example, Tajbiul (2018) outlined that 
"education in distance mode by broadcasting media is still most convenient and cost effective to expand and ensure education for all" (Tajbiul, 2018, p. 1);

\section{Educative message // Feedback Communication process}

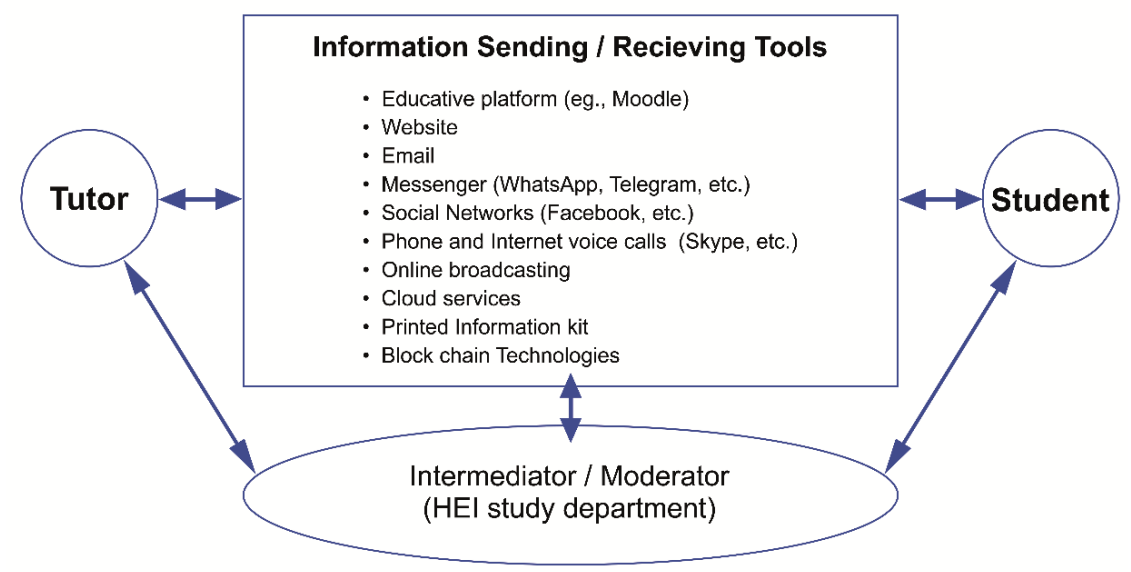

Figure 1. Communication Process Solutions for Distance Learning (designed by authors)

- Messengers, such as WhatsApp, Telegram and others are modern, powerful and often underestimated personalized communication tools. The advantages of these tools are their high personalization, possibility to organize and manage group chats, option to share files, option to make live broadcasting and record it, an excellent opportunity to contact a student who doesn't show any signs of activity for a while anytime and anywhere, being sure he/she has got the information as a delivery report is seen immediately. It is also a perfect tool to give to a distant student a sense of appreciation and support by an education establishment. These tools are supported by mobile devices. As stated by Pucciarelli \& Cantoni- (2012), p. 5, "mobile devices may be a convenient source of information and tool for communication in order to support formal and informal learning".

- Social networks (Facebook etc.). It's a known fact the Facebook Empire has grown from an internal network of Harvard College (Brandwatch, 2019). It is hard to underestimate its meaning in the modern life and communication process. However, its application for distance learning is very little appreciated by the education establishments. Facebook groups, pages with link to information, 
possibility to share information within a click, chats, interactivity these advantages of social network must be fully used by a university or a college;

- Cloud services. The cloud promotes more efficient use of IT resources, such as a reduction in costs, human resource savings. Cloud services can contribute to creation of common data base of several establishments, especially if double or joint diploma programs are provided. These technologies could be used in appliance with other formal communication tools;

- Kits of printed information. Even despite the fact that nowadays technologies contribute to fully automatized and online effectuated study process development, still getting of printed information materials (prospects, booklets, reminders, questionnaires, test books, manuals) makes a distant student feel supported. Sometimes this old school tool can contribute to the communication process as well;

- Blockchain technology. Modern scientists observe many possibilities of block chain technology in the process of education. It should be especially evaluated as a useful tool in a distance education as it enlarges many capabilities at once. For example, digital diplomas could be issued thanks to this technology altogether with a "digital badge", a summary of all courses and modules obtained throughout lifelong learning process. This virtual badge could be shared online and be used as a confirmation of statuses for human resource representatives and other interested persons. The blockchain ledger can match all kinds of educational information with the user's unique ID. It includes learning behavior in class, micro academic project experience, and macro educational background, etc. (Chen, $\mathrm{Xu} \& \mathrm{Lu}, 2018$ ).

As formulated by Sharples (2018), the education approach in the Mobile Age should be re-shaped taking into consideration both conversational and technological factors. Regarding the nowadays education, it removes the solid ground of classroom instruction, and of education as the transmission or construction of knowledge within the constraints set by a curriculum, and replaces it with a cybernetic process of learning through continual negotiation and exploration. This can be seen as a challenge to formal schooling, to the autonomy of the classroom and to the curriculum as the means to teach the knowledge and skills needed for adulthood. But it could also be an opportunity for technology to bridge the gulf between formal and experiential learning (Sharples, 2018, p. 8). 


\section{Results}

The research findings show: 1 . Demographic decrease and open market of education means high competitiveness for the HEIs of the Baltic States. 2. Distance education tools impressively contribute to the market share increase and horizon enlargement for HEIs of the given region. 3. Distance learning must become more communicative and flexible, ensuring fast connectivity, individual approach and a possibility to asses student's needs. 4. The selling of education services should be enriched with selling experience. 5. A method of Four Experience realms application solutions for distance learning has been designed by the authors. 6 . The approach to modern distance learning should combine both formal and informal communication. 7. Technological solutions to ensure both formal and informal communication process for distance learning have been offered by the authors. 8. Offered methods and solutions should contribute both to students' retention and their overall satisfaction with distance learning process that will lead to competitiveness increase of the related HEIs.

\section{Conclusions}

The development of the Internet and communication technology has revolutionary changed the education contents and methods. Due to current demographic decrease in the Baltic States together with open education market of the EU, the HEIs of the mentioned region are experiencing high competitiveness pressure. Dissemination of distance learning could become a key to market share expansion for offered educational services and a tool to competitiveness increase. However, the efforts to retain a student within a process of distance learning should be maximized. To achieve this, the authors of the research propose their recommendations for student's retention during distance learning process, based both on application of Four Realms of Experience model together with formal and informal communication approaches and modern technological solutions.

\section{References}

Basha, A., Abdulreda, A. \& Hatem, H. (2019). Investing Social Media to Offer and Eclectic of Information: Moodle Cloud. IRJCS: International Research Journal of Computer Science, Volume VI, 38-46. doi:10.26562/IRJCS.2019.MRCS10080.

Black, D., Bissessar, C. \& Boolaky, M. (2019). Online Education as an Opportunity Equalizer: The Changing Canvas of Online Education. Interchange 50(3), 423-443. doi:10.1007/s10780-019-09358-0. 
Bornschlegl, M. \& Cashman, D. (2018). Improving Distance Student Retention Through Satisfaction and Authentic Experiences. International Journal of Online Pedagogy and Course Design, 8(3), 60-77. doi: 10.4018/IJOPCD.2018070105.

Chen, G., Xu, B., Lu, M. et al. (2018). Exploring Block Chain Technology and Its Potential Applications for Education. Smart Learning Environments, 5. doi:10.1186/ s40561-017-0050-x.

Clemons, S. (2005) Encouraging Creativity in Online Courses. Retrieved from: http:// www.itdl.org/journal/jan_05/article05.htm.

Distance learning definition. (2018). Cambridge Learner`s Dictionary. Retrieved from: https://dictionary.cambridge.org/dictionary/english/distance-learning.

Distance Learning definition. (2018). Merriam - Webster Dictionary. Retrieved from: https://www.merriam-webster.com/dictionary/distance\%20learning.

Dehtjare, J. (2019). Digitalization of the Hospitality Industry and its Impact on Education. Collective monograph "Development and Transformation Processes in the Tourism Industry under the Conditions of Globalization". Klaipeda State University of Applied Science. Retrieved from: http://ebooks.kvk.lt/einfo/1811/development-and-transformationprocesses-in-the-tourism-industry-under-the-conditions-of-globalization/).

E-learning platform definition. (2018). Retrieved from: https://www.litmos.com/ platform/e-learning-platform-definition.

Gonsalez, R. (2010). The Use of Emails and Blogs in Educaion. Retrieved from: https:// www.slideshare.net/RoyZ112/the-use-of-emails-and-blogs-in-education.

Moodle vs E-learning platform comparison chart. (2018). Retrieved from: https://www. getapp.com/education-childcare-software/a/moodle/compare/braincert/.

Pucciarelli, M., \& Cantoni, L. (2012). Mobile Access to Knowledge. Retrieved from: https://www.researchgate.net/publication/259754675.

Sharples, M. (2018). Learning As Conversation: Transforming Education in the Mobile Age. Retrieved from: http://www.academia.edu.

Tajbiul, H. (2018). Techniques of Educational Broadcasting in Distance Mode and Its Social Implication. Sociology and Anthropology, 6(6), 557-562. doi: 10.13189/ sa.2018.060606.

The History of Facebook. (2019). Retrieved from: https://www.brandwatch.com/blog/ history-of-facebook/.

Zumoko. AR for Education and Learning. (2018). Retrieved from: https://www.zumoko. com/industries/education-and-learning/.

Khudenko, К. Худенко, К. (2019). “Vymirayem, uyezzhayem, no dovol'ny, kak nikogda. Politologi i uchenyye obsudili demografiyu." Вымираем, уезжаем, но довольны, как никогда. Политологи и ученые обсудили демографию. [We are dying out, leaving, but happy as ever. Political scientists and scientists discussed demography.] Retrieved from: https://rus.delfi.lv/news/daily/story/vymiraem-uezzhaem-no-dovolny-kaknikogda-politiki-i-uchenye-obsudili-demografiyu.d?id $=50820627$. 